\title{
FOOD TOURS IN THE CONTEXT OF MULTICULTURALISM OF TOURISM DESTINATIONS: THE CITY OF DUBAI AS AN EXAMPLE
}

REHAB MOSTAFA SHARAF ELDEAN

THE HIGHER INSTITUTE OF TOURISM AND HOTELS, KING MARRIOTTE, EGYPT

\section{Abstract}

Food tourism is closely related to cultural and heritage tourism. Food tourists are experiencing the culture of a destination through tasting its national dishes and traditional cuisines. Most major countries around the world have their special food which is considered as a characteristic of a particular destination. Food is a very important part of the tourism product and it is involved into the marketing plans in many countries. Therefore, food is considered one of the factors that tourist consider when they choose a tourism destination. Food tasted by tourists is playing a major role in impressing them and might make them come back again and again to the same destination. Specialized food tours have emerged in concert with the growing interest in, and demand for, authentic cultural tourism experiences.

The study aims to represent the importance of food tours in expressing the identity and culture of countries and how food tourism is an important element of the intangible heritage. Some countries have their own particular cuisines or national dishes while others have no special cuisine due to the multicultural nature of these countries such as Canada, New Zealand, Australia and United Arab Emirates in the Middle East. The study sheds the light on the importance of food tours within the intangible heritage frame. It discusses the importance of food and gastronomy in multicultural countries from the theoretical point of view through the literature review and analysis. The importance of food tourism in the city of Dubai as a cosmopolitan city and reasons behind the recent growing and popularity of food tours in the city are also represented in this study.

KEYWorDS: culinary tourism, food tours, food tourists, international cuisines, tourism attractions

\section{INTRODUCTION}

Today, food tourism is considered one of the most important and popular sectors of tourism industry. Food is considered a basic need for any tourist and plays a vital role in attracting tourists to a specific tourism destination. In fact, food tourism is focusing on food as an attraction of a destination 
(Shan \& Shende, 2017). Food is one of the most essential components of the tourist experience during his visit to a tourism destination. Tourists may travel to some destinations just to experience food products of these destinations such as Napa Valley in California, Lyon in France, Tuscany in Italy, or Yarra Valley in Victoria at Australia. These regions have established an excellent reputation for their food products. Therefore, big numbers of tourists are visiting these places to experience their food products (Hall \& Sharples, 2003).

According to the World Food Travel Association's (WFTA), several American leisure tourists consider food and culinary activities among major motivations when they decide to travel to a tourism destination (Travel Age West, 2017).

Food tourism could be a main factor for popularizing a tourism destination globally. It is considered one of the most effective ways of introducing and explaining a nation`s cultural heritage (Shan \& Shende, 2017). Food is expressing the identity and culture of communities and is therefore an important element of cultural and heritage tourism (Cusak, 2000). Experiencing a country's food is a very effective way to understand its culture and heritage (MacDonald, 2001). Therefore, food influences most of tourists decision making in choosing a tourism destination (Hall \& Sharples, 2003).

Food festivals and events play an essential role in affirming cultural values and identities of communities. Therefore, some communities started to conduct food festivals and events to reinforce food tourism and to promote their countries as attractive tourism destinations. In fact, these festivals are attracting both domestic and international tourists as families and friends like to attend different activities in food festivals (Rusher, 2003).

\section{FOOD TOURISM AND FOOD TOURISTS}

Food tourism is defined as a visitation to primary and secondary food producers, food festivals, gastronomic events, food fairs, restaurants, cooking sessions and particular destinations for which food experiencing is the main motivating factor or at least one of the main reasons to travel for visitors (Hall \& Sharples, 2003).

Culinary tourism is considered as another subset of food tourism. It is defined as "the pursuit of unique and memorable eating and drinking experiences." However, culinary tourism is more than just trying new and exotic foods; it unites anthropology, culture, folklore, and historical backgrounds and can include ethnic recipes, international cookbooks, food festivals, cooking shows and schools, food tours, breweries, wineries and 
historical attractions (Curtis, Slocum and Allen, 2015). Thus, in recent years some researchers described culinary tourism as an authentic experience of a sophisticated lifestyle in a safe destination (Herrera, Herraz and Arilla, 2012).

Food tourist is the tourist who visits restaurants, coffee shops and food festivals. His major motivation is an interest in food. This type of tourists enjoys tasting different cuisines, relaxing and enjoying historical and archaeological sites as well. Most of food tourists like to try new and exotic things from different cultures. Some studies represent that most of food tourists are above forty years old (Mitchell \& Hall, 2003).

Local food recipes, often promoted through tourism, reflect local herbs and spices and different traditional cooking methods. Some tourism destinations have remarkable dishes attracting food tourists annually such as Vietnamese pho in Vietnam, Italian pasta, New Orleans gumbo and Montana prime rib (Curtis, Slocum and Allen, 2015).

In recent years, culinary tourism has grown considerably and has become one of the most dynamic and creative segments of tourism. Tourism companies are aware of the importance of culinary arts in order to diversify tourism and stimulate local, regional and national economic development (Herrera, Herraz and Arilla, 2012). Therefore, in some tourism destinations specialized food tours, have emerged in concert with the growing interest in, and the high demand for, authentic tourism experiences (Joliffe, 2003).

Some tourism activities are related to food such as the attendance at a variety of attractions (museums, exhibits, festivals and events). Some destinations have museums focus on food and herbs or contain special exhibits that develop various aspects of food and beverages history and traditions (Joliffe, 2003). Tourists not only eat during their trip, food provides a new opportunity to taste the culture of a particular community or society. Food is an expression of heritage based on historical landscapes and traditional farming methods as well (Curtis, Slocum and Allen, 2015). Various factors are affecting food tourism such as natural resources, climatic conditions, culture and habitat prominence (Shah and Shende, 2017).

According to TripAdvisor, it is suggested that food tours are the most growing experience category in tourism activities as they increased by $61 \%$ in 2016-2017 (Kowalczyk, 2020). 


\section{FoOd FESTIVALS AND Events}

Another attraction for food tourists is food festivals with all types of food activities. That is, Food culture is promoted through food events (e.g., food festivals, farmers' markets, food streets) which enhance the appeal of tourist attractions and strengthen the development of sustainable community economies (Quan \& Wang, 2004). In fact, food festivals and food events are very important promotional tools for culinary tourism in many tourism destinations. Such festivals need all stakeholders to cooperate for promoting culinary tourism in a particular destination (Hall, Sharples \& Smith, 2003). In fact, special events celebrating different types of foods and drinks in a destination provide an excellent opportunity for its economic development (Curtis, Slocum and Allen, 2015).

According to global reports on gastronomic tourism, food events occupy the first place of the most important Gastronomic Tourism activities in the world (expressed by 79\%), followed by Food Tours (62\%), cooking workshops ( $62 \%$ ), food fairs (59\%), visits to markets and food producers (49\%), museums (12\%), and other related activities (20\%) (UNTWO, 2012).

In United States of America, The 2014 Oregon Brewers Festival added $\$ 32.6$ million to the country economy, and California craft breweries generated about \$3 billion in total economic impact in 2011 (Richey, 2012).

In Canada, street foods festivals have been made as a development of food tourism in some cities such as Winnipeg at Manitoba province (Selwood, 2003).

New Zealand also has implemented food festivals and events to develop international and domestic tourism (Rusher, 2003).

In India, there are several food festivals to promote India as a culinary tourism destination such as International Mango Festival, Kashmir Food Festival, Delhi Tourism's Dilli ke Pakwaan Festival, Gujarati Food Festival and Sea Food Festival of West Bengal (Banerjee, 2015).

\section{Food and Cultural Heritage Tourism}

Many people are curious to meet new people and explore exotic destinations, cultures, and traditions. Along with intangible heritage such as music, art, and dance, food has become one of the primary ways for people to explore and experience new cultures and destinations (Croce \& Perri, 2010). For many people food tourism is an opportunity to find something new, real, traditional and meaningful, something represents 
heritage, culture and identity (Hall, Charples \& Smith, 2003). Gastronomy allows tourists to access the cultural and historical heritage of destinations through tasting, experiencing and purchasing food which is considered one of the most effective ways to approach cultures (Gaztelumendi, 2012).

Many regional cultural traditions are linked to food, such as turkey at Thanksgiving, cake at weddings, or candy canes at Christmas. Therefore, food is considered a vital component of cultural identity, as exemplified by the great diversity of gastronomic traditions, not only between different cultures but also within specific traditions and countries (Bardhi, Ostberg, and Bengtsson, 2010). For example, the Mesoamerican countries including Mexico and Central America are sharing similar history, traditions, culture and economy while having different food cultures and traditions. Even within Mexico itself, there are differences in food types and traditions throughout the region. That is, every community has its own specific culinary traditions which represent its culture, folklore and identity (Curtis, Slocum and Allen, 2015). Thus, Culture and habitat prominence are affecting culinary tourism (Shan $\&$ Shende, 2017).

For many tourists, food becomes highly experiential when it is part of a travel experience to a particular destination, it can become sensuous and sensual, symbolic and ritualistic. The most basic meal a tourist eats in a particular country can be etched in his memory forever when it is eaten within surrounded special scenery or at the end of a city tour exploring a new city. That is, food when it is consumed in a special place within special aroma can be memorable and unforgettable (Mitchell \& Hall, 2003).

Many countries have contributed food tours as an important component of tourism marketing plans such as Canada. It is a multicultural country containing immigrants from all over the world. Therefore, it has different cuisines and different food flavours coming from all over the world reflecting the intercultural aspect of the Canadian society. In fact, Canada did not have a remarkable national cuisine which made it open to accept different flavours and cuisines from different countries. It could be said that today`s Canadian Cuisine is not authentic but reflecting different cultures of immigrants from all over the world (Telfer \& Hashimoto, 2003).

In Winnipeg which is the largest city of Manitoba province at Canada, street foods festivals have been made as a development of food tourism in this city. Moreover, it is a successful way to promote the city and attract more tourists to come and visit it (Selwood, 2003). Similarly in other countries such as Australia and New Zealand, they are no particular 
cuisines or national dishes in these countries. Food and Cuisines reflect the cultural diversity of these countries (Telfer \& Hashimoto, 2003).

New Zealand also has used food festivals and events strategy to develop and promote domestic and international tourism. Oysters are considered part of New Zealand's deity heritage and culture. New Zealand is famous for its Bluff oyster which is named after the small town of Bluff located at New Zealand's South Island. Bluff oyster has a unique superior flavour different from other oysters grown in other parts of New Zealand. Therefore, the Bluff Oyster and Southland Seafood Festival have been started in New Zealand since 1996 as a very special event for the city (Rusher, 2003).

\section{Gastronomy as An Element of THE InTANGIBLE Heritage}

In 2005, Mexico presented a cuisine proposal to the UNESCO in order to be included in the Proclamation of Masterpieces of the Oral and Intangible Heritage of Humanity of the same year. The proposal was entitled "People of Corn". However, the Mexican proposal had been rejected in that year because the ritual and symbolic value of corn in Mexican cuisine was not shown well in the proposal.

Then, Mexico presented another proposal to be included in the 2010 Proclamation. The proposal entitled "Traditional Mexican CuisineAncestral, Ongoing Community Culture, the Michoacán Paradigm”. At the same year a proposal for the Mediterranean Diet was presented by Italy, Spain, Greece and Morocco. France also submitted the "Gastronomic Meal of the French" at the same year. In November 2010, the committee for the safeguard of Intangible Cultural heritage accepted the three proposals and listed them in the UNESCO's list of Intangible Cultural Heritage of Humanity (Herrera, Herraz and Arilla, 2012). The approval of these proposals was considered a turning point towards new types of heritage especially gastronomy and food as intangible heritage and its role in different societies (De-Miguel-Molina, et. al. 2016).

\section{ECONOMIC IMPACT OF CULINARY TOURISM ON TOURISM DESTINATIONS}

Food tourism provides several positive impacts on tourism destinations. It provides opportunities for marketing and developing destinations without traditional tourism attractions. Culinary tourism also provides business opportunities for food producers as food in this type of tourism is considered the main interest for tourists. In fact, Food tourism allows communities to turn their food culture and traditions into marketable attractions and creates employment and small business opportunities for local residents (Curtis, Slocum and Allen, 2015). Thus, culinary tourism 
has a vital role in enhancing local economies by encouraging the use of local products (Hall and Sharples, 2003). It has not only a positive impact on hospitality organizations such as hotels and restaurants, but also on farmers and other food producers (Yun, Hennessey, \& MacDonald, 2011). The sourcing of food through tourism provides unique expansion strategies for restaurants, coffee shops and hotels and creates a destination brand which supports other local tourism attractions such as natural attractions, museums, archaeological sites, events and festivals (Curtis, Slocum \& Allen, 2015).

The importance of a destination is related to the differences of the place itself which is in most of cases based its cultural identity. There is a strong relationship between food branding and the promoting of the region itself. Food branding reinforces national brands of tourism destinations (Hall, Mitchell \& Sharples, 2003). Thus, culinary tourism helps in developing local communities involved in tourism and enhancing food and beverage production and development (Curtis, Slocum and Allen, 2015). Some studies have been conducted to represent the guidelines for implementing and developing food tourism, as this would enable marketers to optimise the tourism potential of regional food and to support food tourism marketing (Shan \& Shende, 2017).

That is, culinary tourism promotes local economic development including different professional sectors such as food producers, chefs, markets, etc. (Gaztelumendi, 2012).

\section{The City of Dubai as an Example}

\section{Historical BaCKground of DUbai}

Dubai is the most popular city of the seven Emirates (Sheikhdoms) of the United Arab Emirates (UAE). In 1971, Dubai along with Abu Dhabi, Ajman, Sharjah, Fujairah, Umm al-Qaiwain and Ras al-Khaima joined the federation made by Shaikh Zayed Bin Sultan al-Nhayan. Prior to that time, the region was known as the Trucial States because of some peace treaties were made between the Sheikdoms and UK. Previously, this part of the Gulf Region was controlled by Portuguese from the 1500s till the mid of 1700s. In the nineteenth century, the British dominated and controlled this area according to protection agreement (Al.Qasimi, 1988).

The two powerful tribes at the early times of the region were; the Bani Yas tribe who came originally from the Arabian Peninsula and settled in Abu Dhabi, and the Qawasim who were originally from Persia. The most power subsections of the tribe of Bani Yas were the Al-Bu Falah which settled in 
the land of Abu Dhabi, and the Al-Bu Falasah, which settled around Dubia Creek under the leadership of Shaikh Maktoum Bin Buti (Zahlan, 1987).

Dubai started as a little fishing village in the eighteenth century (Elsheshtawy, 2010). In the twentieth century Dubai had become a sufficiently prosperous port and attracted people from Iran, India and Baluchistan who were encouraged by the rulers to settle there. By the 1930s, nearly a quarter of its population was foreign. In 1971 Dubai joined with Abu Dhabi, Sharjah, Ajman, Fujairah, Umm Al Quain and later Ras Al Khaimah to create the federation of the United Arab Emirates (UAE) which was the idea of Shaikh Zayed Al Nahayan. At the beginning of the twentieth century Dubai has grown into a trading hub in the region (Bagaeen, 2007).

Dubai`s developers fashioned the city of Dubai out of desert which was the biggest achievement (Elsheshtawy, 2010).

\section{TOURISM IN DUBAI}

In the past, Dubai economy was based on fishing, pearling and sea trade. Trade from different countries and inward migration of traders led to the establishment of multicultural communities such as Baluchis from Baluchistan, Bastakas from Iran and Bahrainis from Bahrain. In the 1920s, the pearling industry was affected by the invention of the cultured pearls in Japan. Due to the large-scale of silt dredging from Dubai Creek, the port facilities in Dubai was developed which made Dubai the important centre of trade in the Gulf Region. From 1970s the economic development was started because of the oil production and export. Due to the fact that oil is a depleted wealth, Dubai has started an economic diversification from early 1990s. Service sector industries had been encouraged by both national and international investments in the city of Dubai (Staphenson, 2013).

The financial development in the UAE in general and the encouragement of national and international investment in the city of Dubai in particular led to rapid population growth in the whole country. That is, The UAE adopted a national policy that welcomes international investments and people of different nationalities to come and settle in it. Today, Emirati nationals only represent around $10 \%$ of the whole population of the UAE (Stephenson, 2013).

At the end of the 1970s and the beginning of the 1980s a boom on the construction industry and architecture enhanced the development of service sector industry in the city of Dubai. Dubai rapidly became a business hub for the region and tourism became one of the enablers of Dubai economic growth (Bagaeen, 2007). 
In 1989, the Dubai Commerce and Tourism Promotion Board was established (Laws, 1995). Since that time, Dubai is considered a proactive tourism destination in creating exclusive tourism and hospitality products (Stephenson, 2013). Safety and tolerance of the UAE and in the city of Dubai particularly led to an exceptional growth in tourism and hospitality industry (Stephenson, 2013).

Dubai has several tourism attractions and world records such as Burj Khalifa which is the tallest building in the world. It has also the largest money prize for a horse race in the world (Dubai Cup), the tallest hotel in the world (Gevora Hotel), the biggest observation wheel in the world (Dubai Eye), the biggest man-made island in the world (Palm Jumeirah), the biggest shopping mall in the world (Dubai Mall), and the list goes on. The main reason behind achieving such records is positioning the destination as a city of superlatives and to make it a unique destination. The policy of Dubai government is to make history and to move beyond the geographic, climatic, socio-cultural and economic boundaries (Stehenson, 2013; Bagaeen, 2007; Laws, 1995).

Dubai tourism also based on different types of entertainments such as desert safari activities which include Bedouin dinner, camel riding, dune bashing, Henna drawing and sand boarding. Such activities represent the culture, heritage and traditions of locals of the UAE (Stephenson, 2013).

\section{Culture of The City of Dubai}

Dubai is a highly multicultural city with more than 180 different nationalities. There is no other city house such a big number of people with different cultures from all over the world (Khalaf, 2001; Elsheshtawy, 2010). Therefore, multiculturalism is one of the characteristics of the city of Dubai (Jayanthi, 2016).

In the nineteenth century the Persian king raised the import and export duets which ruined trade in the port of Lingah; the main trading port on the Persian coast at that time. Meanwhile, the ruler of Dubai Sheikh Maktoum bin Hashar encouraged the Iranian merchants to come and move their trade to Dubai for tax-free and cheap land. Then, craftsmen, traders and pearl divers came and settled on the land of Dubai. In 1920s, Sheikh Saied bin Maktoum gave the Iranian merchants permanent residence in Dubai who then integrated into the local population. These merchants came from Bastak region in the sub province of Lar in Iran. Therefore, the area where they settled in Dubai has been called Bastakiyya which was the old town`s port (Kanna, 2011). 
Dubai also has a large Indian community that constitutes 30 percent of its population. The city is called by some groups "the best-run Indian city". The largest communities in Dubai are in order; Indian, Pakistani and Bangladeshi communities (Jayathi, 2016).

Local culture and traditions are not promoted as central and holistic elements of the Dubai tourism experience. Unique forms of architecture and constructions are significantly attracting global attention and iconographic appeal. However, giving the past a considerable importance helps to understand the local culture, national identity and the indigenous attributes of the city. Therefore, tourism potential role in solidifying local cultures and local traditions should be assessed (Stephenson, 2013).

New forms of cultures and heritage are manufactured in Dubai rather than enhancing the historical identification and local culture. The modern culture that appeared after the boom of construction that happened in the city bypassed the real culture and history of Emirati society. The past of this city has lost its hold because of the future legacy which is called the "detraditionalisation of social order". Thus, Dubai has become a place of cultural fluidity rather than a place of deeply rooted historical identity and local heritage. A new cultural fabric had been invested and a new culture and heritage had been invented in a familiar western sense based on multiculturalism and modernity (Bagaeen, 2007).

Dubai has a lack of cultural consistency due to modernisation and urbanization (Stephenson, 2013). However, some attempts have been made to restore some historical areas of the city such as steps have been taken to restore and preserve what remains of the Bsatakiyya district "Al Fahidi historical district" close to Dubai creek. In this area, there are about 40 houses of merchants originally from Bastak region in Iran (Orbasli, 2007). In the late 1970s and after federation, the old building of Al Fahidi fort has been restored and converted into a national museum which is Dubai Museum (Elsheshtawy, 2010).

That is, the modern society of the city of Dubai causes a social challenge to advance tourism agenda which prefers culturally rooted experiences including the original local identity, heritage, real culture and traditions of the destination (Stephenson, 2013). The most important feature of the city of Dubai is the cultural diversity and one of its beauties. Different cultures are living in a social harmony cannot be seen in any other place around the world (Jayanthi, 2016).

Based on this multiculturalism Dubai has successfully started promoting tourism through food tourism and food tours. Food and beverages in Dubai reflect the multicultural society of this city. Restaurants and coffee shops 
in Dubai also reflect the magnificent diversity of this city. By this way Dubai uniquely expresses itself as a destination of distinction. These types of tours in the city of Dubai represent the multicultural concept and the socio-cultural diversities of the city (Stephenson, 2013).

\section{FOOD INDUSTRY IN DUBAI}

Food industry in the GCC in general and the UAE in particular has grown dramatically after oil discovering in the region. The largest food consumers in the Gulf Region are Saudi Arabia and the UAE. The Population growth, the high GDP per capita and the rising tourism industry are the main factors behind the growing of food industry in the GCC. Therefore, the demand for food in the GCC is expected to grow from about 52 million MT in 2018 to around 61 million MT in 2023. Saudi Arabia and the UAE will remain the largest food consumers in 2023 (Alpen Capital, 2019).

Recently, the city of Dubai has implemented some strategies to boost tourism and hospitality industries in order to diversify the oil based economy. Dubai is also hosting some events such as sport, shopping and food festivals to enhance tourism industry in the city. Thus, the tourists' number has dramatically increased in the last few years. That is, tourism is considered one of the major factors to drive food consumption in Dubai. Total investments in the UAE`s food and beverage sector are estimated by around US\$ 10.8 billion, 21\% of which is foreign capital, according to Dubai Export Department (2011-2016). Due to the arid climate conditions, the UAE imports around $85 \%$ of its food from all over the world especially India. The UAE has multicultural communities with about $85 \%$ of the population are expatriates which increased the demand for cuisines variety (Alpen Capital, 2019).

\section{Emirati Cuisine and Culture}

The production of local cuisine in a destination reflects its culture and identity and can be also utilized in tourism and hospitality industries. Cosmopolitan cities and tourism destinations usually cater to cuisine that represents the common ethnicity of the locality, and multicultural influences through the fusion of foreign and local food types. The development and promotion of local cuisine can arguably contribute to sustainable tourist experiences and the long-term sustainability of local cultures (Reynolds, 1993). However, although Emirati local cuisine is special (Iddison, 2001), it remains not clear in UAE's food and restaurant industry. The native population of the UAE constitutes around 10 per cent of the residents while other nationalities such as South Asians, Iranians, Arabs and Africans form the majority (Kanna, 2011; Elshestawy, 2010). Therefore, Emirati local food is infrequently available in most of Dubai 
restaurants. Instead, other Arabic food is popularised as local food such as Lebanese and Moroccan cuisines. That is, in representing the Arabic culinary arts, the Moroccan and Lebanese restaurants often achieve highly commended awards in the city of Dubai (Stephenson, 2013).

Emirati cuisine shares its roots with the Indian cuisine. This multiethnic society made older Dubayyans often speak Arabic, Indian and Persian. Even the local dress had been influenced by the Persian and Indian dress at least prior to the oil era (Kanna, 2011).

When it comes to the culinary industry in Dubai, for instance, the most popular chefs worldwide have established their restaurant brands there such as Gordon Ramsey's 'Verre', Gary Rhodes's 'Mezzaniene' and Jamie Oliver's 'Jamie's Italian' (Huang, 2011).

\section{Dubai Food Festival}

Food festivals are among the most important activities for gastronomic tourism growth. Food festivals have positive impacts on both culture and economy. In general, Food festivals and events are held in the United Arab Emirates such as Abu Dhabi Food Festival (ADFF) which is held periodically in the month of December. It attracts tourists, families and ordinary people to enjoy food activities and some of the most exciting street foods in the world (Sandybayev, 2018).

In 2015, Dubai has started Dubai Food Festival (DFF) to showcase restaurants, popular chefs, different cuisines, food activities, adventures and food entertainments. It is an important tool to promote the city of Dubai as a culinary destination along three weeks of food adventures. It promotes the diversity, creativity and the multicultural aspect of culinary in Dubai as it reflects the diversity of the city through foods (Jayanthi, 2016).

That is, food festivals and events in the UAE are considered the fastest growing culinary and hospitality events in the MENA region (Sandybayev, 2018).

\section{Culinary Tourism and Food Tours in DUbai}

From what are discussed before, it should be kept in mind that food tourism is a growing industry and one of the most important segments of tourism market. It links culture with tourism and plays a vital role in supporting local culture (Richards, 2012).

The increasing number of tourists to the city of Dubai helped in making Dubai a leading destination in food and beverage industry in the Middle East. According to some studies, Dubai is ranked the fourth in terms of 
international overnight visitors and the first in respect to the overnight visitor spend per day (KPMG, 2018).

There are cities around the world that are considered as highly culinary attractive. Some of these cities have a long gastronomic tradition such as Rom, Paris, London, Tokyo and Lyon. On the other hand, there are some cities have emerged in the last few years on culinary map such as Dubai (Derek, 2020).

The emerging of food tours in the city of Dubai in the last few years helps in representing and understanding the diversity of geo-ethnic identities and socio-cultural diversities in the city, as well as advancing a deeper ethnic awareness of the complexities of Dubai's history and heritage (Stephenson, 2013). Dubai is a multicultural city with several ethnicities which made it a destination for a wide variety of cuisines (Jayanthi, 2016). The cuisines diversity reflects the demographics of the city. The visitor to the city of Dubai can enjoy Persian, Indian, Pakistani and Arabian cuisines (Figs. 11, 12, 13). However, Arabian and Indian cuisines are the most popular and the top choices for tourists, residents and locals alike. According to some recent studies, veganism and East Asian foods have become very popular in Dubai (Kanna, 2011).

In the UAE, small restaurants offering affordable sandwiches, fried chicken, French fries are commonly found almost everywhere. Cafés which are offering "Karak tea" are scattered around the whole country as well. "Karak tea" or "Karak Chai" is originally from India but deeply rooted in the UAE long time ago. Over years it has become part of Emirati cultural heritage (KPMG, 2018). There is a historical reason behind the popularity of Indian and Persian foods in the city of Dubai that is a large number of Indian and Persian merchants migrated to the city in the early twentieth century (Kanna, 2011).

Thus, the gastronomic attractiveness of a city is influenced the diversity of its gastronomic offers. In 2018, Dubai is classified as one among the cities with the largest number of national cuisines in the world as it has 62 different national cuisines. It is classified in respect after New York, London, Toronto, Chicago, Paris, Berlin and Melbourne. That is, the multicultural society of Dubai impacts gastronomic tourism and food tours in the city (Kowalczyk, 2020). Since the culture is closely related to food, Dubai has different types of foods reflect the nature of life and the cultural diversity of the city. It is one of few places of the world that offer affordable foods of cuisines from all over the world. Different cuisines that can be found in Dubai with affordable prices allow tourists to taste and enjoy several types of food in one place (Jayanthi, 2016). 
Most of food tours in the city of Dubai are walking tours in old Dubai; Deira and Bur Dubai traditional neighbourhoods where the city of Dubai emerged and grew (Al Fahidi Historical District). In these areas the tourists can feel the real essence of the city (Figs. 1,2). In this type of tours tourists enjoy walking through old houses and tasting the most ethnic traditional types of food and beverage in Dubai. Food tours in the city of Dubai show the cosmopolitan lifestyle of the city through food. In these tours the success of integrating varies ethnic groups in one place can be shown (Elsheshtawy, 2010).

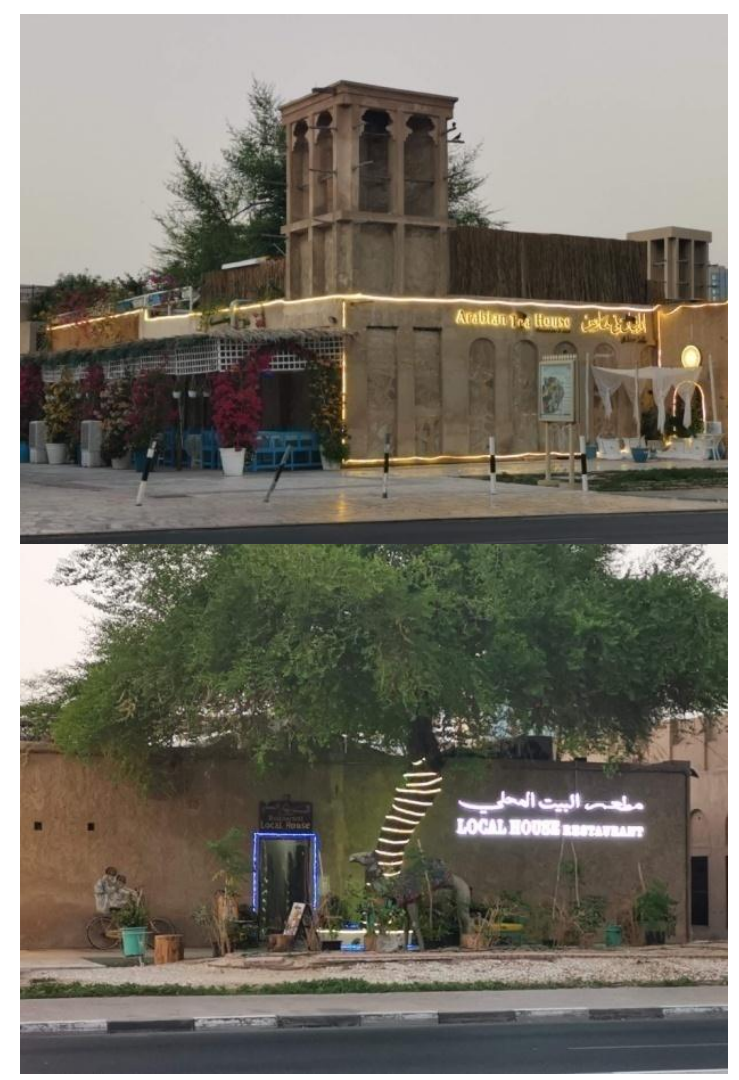

\section{Figures 1,2: Traditional Restaurants in Al Fahidi Historical District (Bastakyya) - Bur Dubai.}

Al Satwa is a place for affordable food in the city of Dubai and some food tours are taking place there. It is a traditional low income district with old buildings show the history of the city of Dubai. It is located behind the luxurious Sheikh Zayed Road (Elsheshtawy, 2010). Restaurants there offer cuisines from different parts of the world. Iranian, Asian and Arabic cuisines can be found in Satwa (Figs.3,4) 
In Al Satwa, Several Indian restaurants are locating and considered part of the heritage of the city as the local Emirati cuisine is largely driven from Indian cuisine (Figs.5, 6). Indian cuisine is very popular in Dubai as Indian merchants and workers came to the city of Dubai in the 1920s as it has been illustrated previously (Kanna, 2011). Thus, restaurants serving Indian food are very popular and widely available in the UAE in general and Dubai particularly (Jayanthi, 2016).

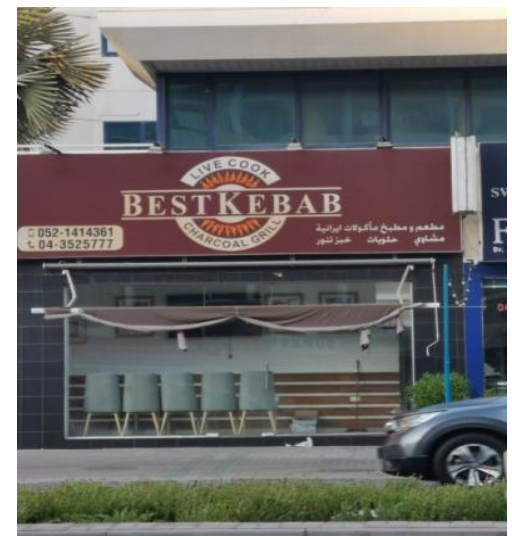

Figure 3: Iranian Restaurant in Bur Dubai (Satwa)

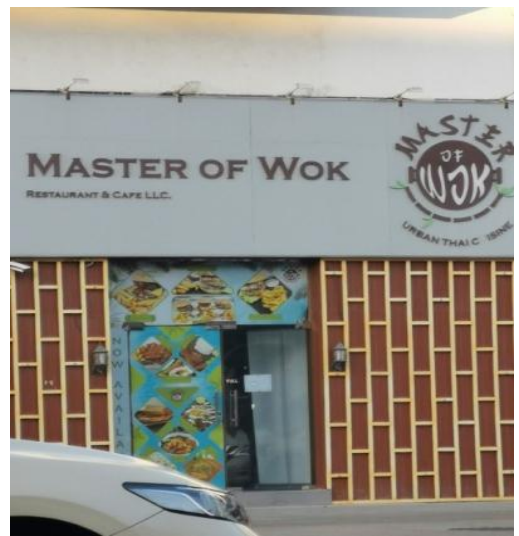

Figure 4: Asian Restaurant in Bur Dubai (Satwa)

To maintain the traditional Emirati cuisines Dubai has some local restaurants offer wide variety of Emirati ethnic foods (Khalaf, 2001) such as Al Fanar restaurant which has authentic Emirati cuisine and an architectural style reflects the old houses of Dubai. Therefore, it is commonly included in food tours of Dubai to enjoy local food with the old Dubai authentic ambience.
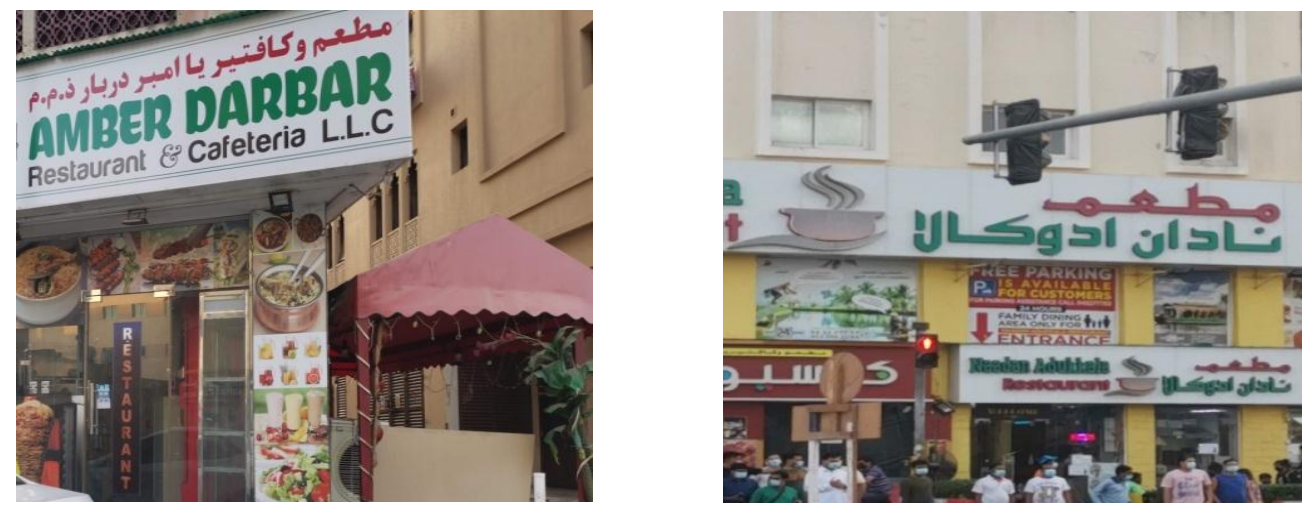

Figures 5, 6: Indian and Pakistani restaurants in Bur Dubai (Satwa). 


\subsection{SPICE SOUK (MARKET)}

It is located in Bur Dubai neighbourhood at the old city of Dubai close to Dubai Creek. It is an outdoor market in which traders are selling spices, dates, frankincense and herbs. There are also some traditional food and beverage stalls where locals, residents and tourists can experience food tasting (Elsheshtawy, 2010). Thus, food tourists enjoy visiting the spice souk of Dubai to identify and buy different spices used by locals. The common spices used by Emirates are cardamom, carom seeds, cinnamon, ginger, dried lemon (loomy) and saffron which is the king of spices. Therefore, Spice Souk is usually included in Dubai food tours (Figs. 7, 8, 9).

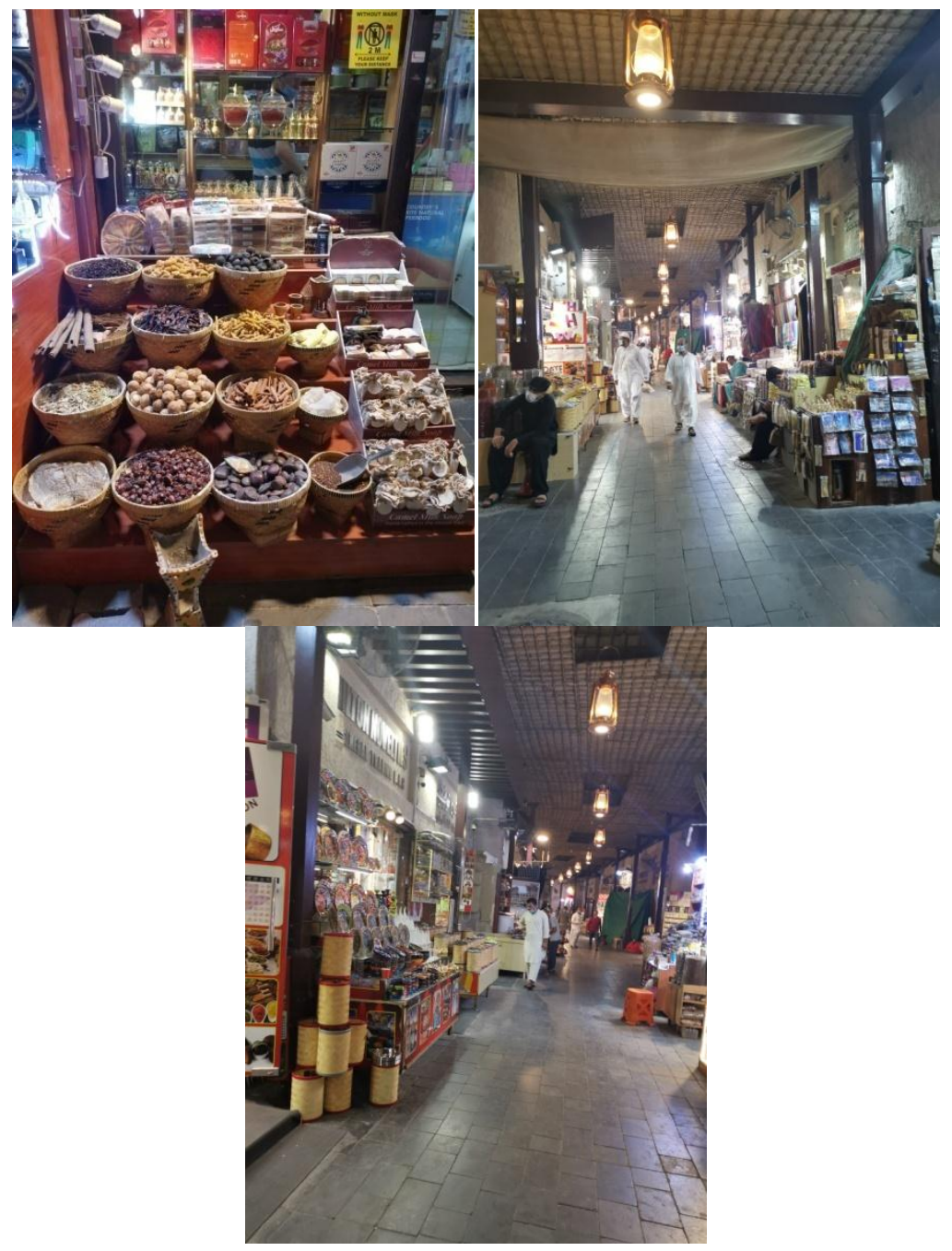

Figures 7,8,9: Spice Souk at Deira - Old Dubai. 


\subsection{FiSH SOUK (MARKET)}

The fish Souk (market) in Dubai is considered a part of the old city (Kanna, 2011). Fish is considered among the traditional food of local Emirates. In old times, the main meal of local Emirati family consisted of fish, rice, vegetables or meat. Since the city of Dubai was a fishing village, fish is considered the main traditional type of food for Dubayyans. Thus, Fish Souk was included in food tours by some tour operators to represent traditional Emirati cuisine (Khalaf, 2001). Today, this fish market in old Dubai is permanently closed. Previously, during the visit to the fish market, the tourist used to see different types of local fishes and understand different fishing methods and fishing tools used by early Dubayyans.

\subsection{KARAK CHAi (TEA)}

Tea as a beverage is the second popular drink in the world after water. The tea plant appeared for the first time in China and then was introduced to other countries with suitable growing climate around the world. Tea moved from China to Japan where the tea ceremony was created for the first time in the $15^{\text {th }}$ century AD. Then, tea was introduced to European countries and Africa. That is, tea has been adopted by many countries and has been closely connected to their cultures and traditions. In the $20^{\text {th }}$ century, America invented the iced tea in 1904 and tea bags in 1908 (Joliffe, 2003).

When it comes to tourism and hospitality contexts, there are tea destination countries. They are the tea-producing destinations such as India, China, and Seri Lanka. Special tea tours are organized by tour operators in China, Mongolia, Tibet and Iran. That is, tea is closely connected to tourism as some tourists are interested in having authentic experience related to tea as a beverage in a particular destination. Tourists who want to experience history, traditions, cultures related to tea consumption are called tea tourists. Tea tourism can be defined as "tourism that is motivated by tourist interest in the history, traditions and consumption of tea" (Joliffe, 2003).

Historically, coffee and tea houses appeared at the end of the seventeenth century. In the eighteenth century their popularity was increased as they became drinks for only upper classes. In fact, these houses were serving coffee, tea and other refreshments (Kowalczyk \& Derek, 2020).

In Canada, some studies had been conducted for enhancing and developing tea tourism. However, there is a little to be found in literature about tea tourism.

In England, there are special tea tours offers by travel agencies especially in the land of Shires and Spires. Such types of tours are focusing on the tea in England including lectures on tea history in England and English 
traditions related to tea such as the afternoon tea tradition. The tour also includes a visit to some places for tea such as the orangery of Kensington palace (Joliffe, 2003).

Each country that has adopted tea as a beverage has developed its tea customs. Traditions of one country have influenced that of another, as the traditions and rituals related to tea consumption are usually imported from other cultures.

With this colourful history of tea and unique cultural traditions in different societies tea is a natural focus for travel and it is related to Food Tourism (Joliffe, 2003).

The Karak Chai is a hot popular beverage for both Emiratis and expats alike. It is the most affordable hot beverage can everyone has in the UAE. Cardamom, Saffron, Cinnamon, Ginger, Sugar and milk are added to ground black tea and boiled several times for few minutes to prepare this popular beverage. Karak is the name adopted by UAE locals for this type of tea which means "strong or heavy" in Hindi language. Karak Chai has Indian origin but since 1960s, it has become a part of Emirati culture (Figure 10). In India, "Masala Chai" as it is called by Indians, is the traditional and the most popular hot drink. In America and some other countries, a similar beverage with milk is made and is called "Tea Lattes" (Diana, 1999).

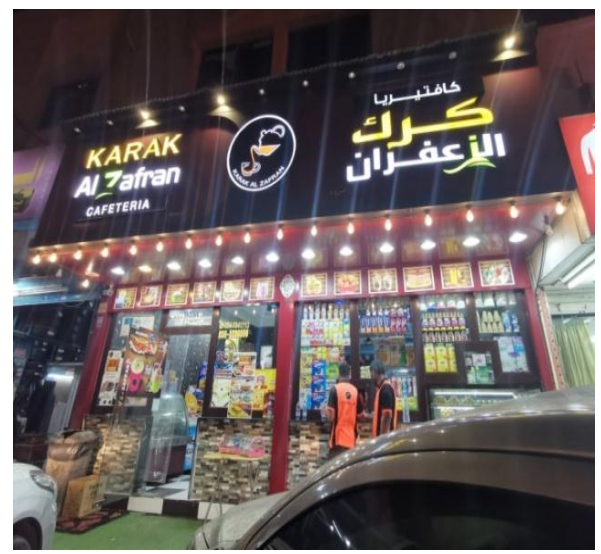

Figure 10: Karak Chai ( tea) Cafeteria.

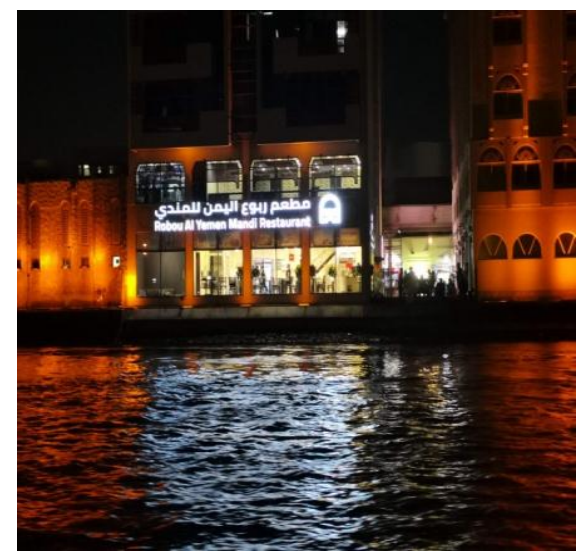

Figure 11: Arabian Restaurant close to Dubai Creek 

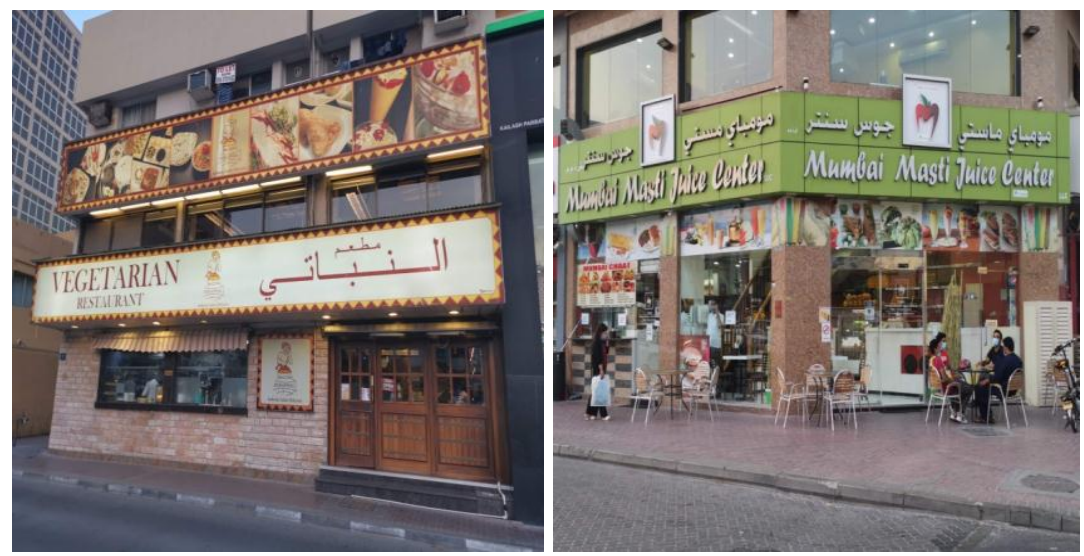

Figure12, 13: Indian Restaurant and Cafeteria - Bur Dubai

\section{CONCLUSION}

Culinary tourism is not a standardized tourism product but it is an authentic experience allows tourists to understand cultures and create strong relationship with destinations. It is an attraction which could make a visitor extends his stay in a destination to see and attend more activities and events related to food. In fact, gastronomic tourism attracts more spending visitors into a destination. As it is mentioned in this study, culinary tourism plays a vital role in enhancing economic development of tourism destinations. It also boosts cultural heritage and supports local communities. Almost all economy sectors can benefit from this type of tourism as a link between food producers at all levels and tourism companies should be established to make successful food tours.

The government of the city of Dubai has started promoting the city via food tourism. It is a multicultural city as hundreds of different nationalities. The emerging of food tours in Dubai helps in representing and understanding the diversity of geo-ethnic identities and socio-cultural diversities in the city. In this type of tours tourists enjoy walking through old houses and tasting the most ethnic traditional types of foods and beverages in Dubai. Food tours in the city of Dubai show its cosmopolitan lifestyle and its multicultural nature. In these tours the success of integrating varies ethnic groups in one place can be shown. That is, Dubai has a very successful experience in culinary tourism with its different activities and food tours.

To sum up, ongoing development for gastronomic tourism in many countries in the Middle East is highly needed to boost their local economy and enhance their cultural heritage. 


\section{REFERENCES}

Alpen Capital. (2019), GCC Food Industry, UAE. www.alpencapital.com

Al-Qasimi, M. (1988). The myth of Arab piracy in the Gulf. London: Croom Helm.

Bagaeen, S. (2007), Brand Dubai: The Instant City; or the Instantly Recognizable City, International Planning Studies, Vol. 12 (2), pp. 173-197

Bagaeen, S. (2007). Brand Dubai: The instant city; or the instantly recognizable city. International Planning Studies, 12(2), pp. 173-197.

Banerjee, M. (2015), Food Tourism: An Effective Marketing Tool for Indian Tourism Industry, International Journal of Science and Research, Vol. 4 (6), pp. 795-800.

Bardhi, F., Ostberg, J., \& Bengtsson, A. (2010). Negotiating cultural boundaries: Food, travel and consumer identities. Consumption Markets and Culture, 13(2), pp.133-157.

Carpio, C. and Isengildina-Massa, O. (2009). Consumer willingness to pay for locally grown products: The case of South Carolina. Journal of Agribusiness, 25(3), pp. 412-426.

Croce, E., \& Perri, G. (2010). Food and wine tourism: Integrating food, travel and territory. Wallingford, UK: CAB International.

Curtis, K. Slocum, S. and Allen, K. (2015), 'Why Farms and Food Tourism?' in Baker, T. Bekkerman, A. and Curtis, K. (eds.), Farm and Food Tourism: Exploring Opportunities, Western Sustainable Agriculture Research and Education, Utah, Utah State University Cooperative Extension-Logan.

Cusack, I. (2000). “African cuisines: recipes for nation building?”, Journal of African Cultural Studies, Vol. 13(2), pp.207-225.

Derek, M. (2020), Conclusion, in Kowalczyk, A. \& Derek, M. (Eds.), Gastronomy and Urban Space, Changes and Challenges in Geographical Perspective (p.343), Switzerland: Springer Nature.

Diana, R. (1999), Chai; the Spice Tea of India, in Debora, B. \& Robin, C. (Eds.). Story Publishing, Washington DC: Library of Congress.

Elsheshtawy, Y. (2010). Dubai: Behind an urban spectacle. London: Routledge.

Gaztelumendi, I. (2012), "Global trends in food tourism”, in Global Report on Food Tourism, Vol. 4, Madrid, UNWTO. 
Giddens, A. (1994). Beyond left and right: The future of radical politics. Stanford, CA: Stanford University Press

Hall, C. \& Sharples, L. (2013). 'The consumption of experiences or the experience of consumption? An introduction to the tourism of taste', in Hall,C. Sharples, L. Mitchell, R. Macionis, M. \&Cambourne, B. (eds.). Food Tourism around the World, Development, Management and Market (pp.1-24). Oxford: Butterworth-Heinemann.

Hall, C. Mitchell, R. and Sharples, L. (2003). 'Consuming plaes: the role of food, wine and tourism in regional development', in Hall,C. Sharples, L. Mitchell, R. Macionis, M. \& Cambourne, B. (eds.). Food Tourism around the World, Development, Management and Market (pp.25-59). Oxford: Butterworth-Heinemann.

Hall, C., Sharples, L., and Smith, A. (2003). 'The experience of consumption or the consumption of experiences? Challenges and issues in food tourism', in Hall, C. Sharples, L. Mitchell, R. Macionis, M. \& Cambourne, B. (eds.). Food Tourism around the World, Development, Management and Market (pp.314-335). Oxford: Butterworth-Heinemann.

Herranz, J. (2012). ".the cuisine of the destination is an aspect of utmost importance in the quality of the holiday experience", Global Report on Food Tourism, Vol.4, Madrid, UNWTO.

Herrera,C., Herraz, J. and Arilla, J. (2012), “Gastronomy's importance in the development of tourism destinations" in the world" in Global Report on Food Tourism, Vol. 4, Madrid, UNWTO.

Huang, C. (2012). Tom Cruise's Burj Khalifa stunts revealed in new clips. The National.http://www.thenational.ae/news/uae-news/tom-cruisesburjkhalifa-stunts-revealed-in-new-clips

Iddison, P. (2001). Memory as a culinary skill and necessity. In H. Walker (Ed.), Proceedings of the Oxford Symposium on Food and Cookery 2000 (pp. 115 -122). Devon, UK: Prospect Books.

Jayanthi, M. (2016), Impact of Multiculturalism on Indian Nationalities in Dubai-UAE, International Conference on Emerging Research for Sustainable Economic Development (ERSED-2016), Dubai.

Joliffe, L. (2003). 'The lure of tea: history, traditions and attractions', in Hall, C. Sharples, L. Mitchell, R. Macionis, M. \& Cambourne, B. (eds.). Food Tourism around the World, Development, Management and Market (pp.121-136). Oxford: Butterworth-Heinemann. 
Kanna, A. (2011), Dubai: The City as Corporation, London, University of Minnesota Press.

Khalaf, S. (2001), "Culture in the United Arab Emirates", in Encyclopaedia of Countries and their Cultures, Macmillan Reference: New York, Vol.4, pp. 2325-2331.

Kowalczyk, A. (2020), Culinary Attractiveness of a City- Old and New Destinations, in Kowalczyk, A. \& Derek, M. (Eds.), Gastronomy and Urban Space, Changes and Challenges in Geographical Perspective (pp. 125-134), the Urban Books Series, Switzerland: Springer Nature.

Kowalczyk, A. and Derek, M. (2020), Relation between Gastronomy and the City, in Kowalczyk A. and Derek M. (Eds.), Gastronomy and Urban Space, Changes and Challenges in Geographical Perspective (pp. 3-52), the Urban Book Series, Switzerland: Springer Nature.

KPMG, (2018), Food for thought, UAE 2018 Food \& Beverage report, UAE. Available at: kpmg.com/ae.

Laws, E. (1995). Tourist destination management: Issues, analysis and policies. London: Routledge.

MacDonald, H. (2001). National Tourism and Cuisine Forum: 'Recipes for Success' Proceedings and Final Report. Canadian Tourism Commission.

Mitchell, R. and Hall, C. (2003). 'Consuming tourists: food tourism consumer behaviour', in Hall, C. Sharples, L. Mitchell, R. Macionis, M. \& Cambourne, B. (eds.). Food Tourism around the World, Development, Management and Market (pp. 60-80). Oxford: Butterworth-Heinemann.

Orbasli, A. (2007). The 'Islamic' city and tourism: Managing conservation and tourism in traditional neighbourhoods. In R.F. Daher (Ed.), Tourism in the Middle East: Continuity, change and transformation (pp. 161-187). Clevedon: Channel View Publications.

Quan, S., \& Wang, N. (2004). Towards a structural model of the tourist experience: An illustration from food experiences in tourism. Tourism Management, 25(3), pp.297-305.

Reynolds, P. (1993). Food and tourism: Towards an understanding of sustainable culture. Journal of Sustainable Tourism, Vol. 1(1), pp. 48 -54.

Richards, G. (2012), Food and the Tourism Experience: major findings and policy orientations, In Dodd, D. (ed.) Food and the Tourism Experience. OECD, Paris. 
Richey, D. (2012). California craft brewing industry: An economic impact study. Berkeley, CA: University of California, Berkeley, and the California Craft Brewers Association. http://www. Californiacraf tbeer.com/wp-content/uploads/2012/10/Economic-Impact-StudyFINAL.pdf.

Rusher, K. (2003). 'The Bluff Oyster Festival and regional economic development: festivals as culture commodified', in Hall, C. Sharples, L. Mitchell, R. Macionis, M. \& Cambourne, B. (Eds.). Food Tourism around the World, Development, Management and Market (pp.192205). Oxford: Butterworth-Heinemann.

Sandybayev, A. (2018). "The Impact of Street and Food Festivals in Gastronomic Tourism through Visitor's Emotions and Satisfaction. A Case of Abu Dhabi Food Festival", International Journal of Tourism and Hospitality, Vol. 4(1), pp. 27-32.

Selwood, J. (2003). 'The lure of food: food as an attraction in destination marketing in Manitoba, Canada', in Hall, C. Sharples, L. Mitchell, R. Macionis, M. \& Cambourne, B. (eds.). Food Tourism around the World, Development, Management and Market (pp.178-191). Oxford: Butterworth-Heinemann.

Shan, G. \& Shende, K. (2017). "A study on the importance of Food Tourism and its impact on Creating Career Opportunities amongst the Residents of Pune city", International Journal of Research in IT and Management, Vol.7 (3), pp. 192-208.

Slocum, S. L. \& Everett, S. (2010, July). Food tourism initiatives: Resistance on the ground. Paper presented at the Fourth International Conference on Sustainable Tourism, New Forest, UK. In C.A. Brebbia \& F.D. Pineda (Eds.), The sustainable world (pp. 745-757). Ashurst, Southampton: WIT Press.

Telfer, D. and Hashimoto, A. (2003). 'Food tourism in the Niagara Region: the development of a nouvelle cuisine', in Hall, C. Sharples, L. Mitchell, R. Macionis, M. \& Cambourne, B. (Eds.). Food Tourism around the World, Development, Management and Market (pp. 158177). Oxford: Butterworth-Heinemann.

U.S. Department of Commerce. (2012). National Travel \& Tourism Strategy. Task Force on Travel \& Competitiveness .http:// travel.trade.gov/pdf/national-travel-and-tourism-strategy.pdf.

United Nations World Tourism Organisation. (2014). World tourism barometer, Volume 12. http://mkt.unwto.org/barometer. 
Yun, D., Hennessey, S., and MacDonald, R. (2011, July 29). Understanding culinary tourists: Segmentations based on past culinary experiences and attitudes toward food-related behaviour. Paper presented at the International CHRIE Conference, Denver, CO. Available at: http://scholarworks.umass.edu/refereed/ ICHRIE_2011/Friday/15/.

Zahlan, R. (1978). The origins of the United Arab Emirates: A political and social history of the Trucial States. London: Macmillan.

De - Miguel- Molina, M. De - Miguel- Molina, B. Santamarina, V. \& Segarra-ono, M. (2016), "Intangible Heritage and Gastronomy: The Impact of UNESCO Gastronomy Elements", Journal of Culinary Science and Technology, Vol. 14 (4), pp. 293-310. 